\title{
Assessment of inflammatory and immunity proteins during falciparum malaria infection in children of Côte d'Ivoire
}

\section{Yapi Houphouet Félix ${ }^{1 *}$, Ahiboh Hugues ${ }^{2}$, Koffi David ${ }^{1}$, Yapo Adou ${ }^{1}$, Bla K. Brice ${ }^{1}$, Monnet Dagui ${ }^{2}$, Djaman Allico Joseph ${ }^{1,3}$}

${ }^{1}$ Laboratoire de Pharmacodynamie-biochimique, UFR Biosciences, Université de Cocody, 22 BP 582 Abidjan 22

${ }^{2}$ Laboratoire de biochimie et biologie moléculaire, UFR de sciences pharmaceutiques et Biologiques de Cocody, Côte d'Ivoire.

${ }^{3}$ Institut Pasteur de Côte d'Ivoire, Département de Biochimie médicale \& fondamentale, 01 BP 490 Abidjan 01

\begin{abstract}
Plasmodium falciparum is the most deadly species of parasite causing malaria in children living in sub-Sahara Africa and constitutes a real problem of public health. Inflammation and immunity are involved in this malaria infection. This present study was undertaken to determine the inflammatory (C reactive protein or CRP, Haptoglobin, Orosomucoïd or AGP) and immunity ( IgG, $\lg A$, IgM) proteins markers concentrations in order to evaluate the immunity and inflammatory proteins secretion concentration and their state in children suffering from Plasmodium falciparum malaria. Patients with positive peripheral blood film for Plasmodium falciparum were compared with subjects without malaria. Giemsa-stained thick blood films were analysed by microscope for plasmodium specie. Haemoglobin and proteins were determined respectively using haematology cell counter and Radial immunodiffusion according to Mancini. Forty seven patients with malaria infection (Plasmodium falciparum) (M/F: 25/22; age 9.7 $\pm 0.27 \mathrm{yr}$ ) and 35 controls (M/F:19/16; age $9.5 \pm 0.39 \mathrm{yr}$ ) were studied. CRP, AGP, Haptoglobin for inflammatory state and immunoglobins (G, A, M) for immunological markers were determined in malaria children and compared with those of healthy subjects. Results showed that, CRP, AGP and IgM were increased in malaria children for those having high parasite density (exceeding 2000 parasites/ul ) as compared to controls $(p<0.01)$. Parasite density with Plasmodium falciparum is high in children under 5 years old. In the malaria infection (Plasmodium falciparum), CRP and AGP for inflammation markers and IgM for Immunity Makers were disrupted. These disruptions were attributed to the organism defense against Plasmodium falciparum.
\end{abstract}

Keywords: humoral proteins, Plasmodium falciparum, children, Côte d'Ivoire

\section{INTRODUCTION}

Malaria remains a major health problem in most tropical countries. In Cote d'Ivoire, malaria is highly endemic with Plasmodium falciparum, the most deadly specie ( Tripathi et al., 2005). It occurs to be the first major cause of morbidity $(42,28 \%)$, and mortality $(15,29 \%)$ in children under five years old (Kone and Penali, 1990; Beugre et al., 2003). This situation is aggravated by the fact that an increase prevalence of drug resistant strain of Plasmodium falciparum continues to reduce the effectiveness of most known anti-malarial (Withe, 1992)

Meanwhile it is obvious that for better therapeutic action we need to understand malaria drugs pathogenesis mechanism. Plasmodium causes biological disorders which are not totally elucidated. When malaria occurs there is destruction of infected erythrocyte, opsonisation of red cells and dyserythropoiesis (Latger-Cannard et al., 2002). When schizontes rupture, host monocytes and macrophages secrete pro-inflammatory cytokines stimulating the production of acute phase protein. An acute-phase protein is defined as one of which plasma concentration increases (positive acutephase proteins) or decreases (negative acute-phase proteins) by at least 25 percent during inflammatory disorders (Gabay and Kusher, 1999). Inflammation constitutes an important part of acute phase response during infection. However, the inflammation 
mechanism in malaria has not been clear and documented. In immunological investigation, an early study showed that malaria may be implicated in the heightened levels of gamma-globulins seen in the tropics (Charmot and Vargues), 1963). But the secretion of gamma-globulins fraction has not been fully understood (Bouharoun-Tayoun et al., 1990; Plebanski and Hill, 2000).

Therefore, the aim of this study was to determine the inflammatory (CRP, AGP, Haptoglobin) and immunity ( $\lg A, \lg G, \lg M)$ markers concentrations in order to evaluate immune and inflammatory proteins secretion concentration and their state children suffering from acute falciparum malaria..

\section{MATERIALS AND METHODS}

Study area: The study was undertaken from June to August 2008 in the medical health and care centre of Anonkoua-koute which is located in the northern part of Abidjan. The Anonkoua-koute village itself is a suburban one which hosts some clinical trials. Malaria transmission is permanent but with some variations of intensity during the seasons. The heavy rainy season occurs from May to August.

Subjects: Forty-seven patients under 15 years old with positive peripheral blood film for $P$. falciparum admitted to the health care center of Anonkoua-koute were included in this study. They were diagnosed positive for malaria if thick and thin Giemsa-stained blood films showed the presence of Plasmodium species, temperature $\geq 37.5^{\circ} \mathrm{C}$ and no other obvious cause for the illness. Falciparum malaria disease was diagnosed on the basis of clinical symptoms and parasite positive blood film (Garcia and Burkner, 1993). Informed consent was obtained from guardian accompanying the sick children. They were informed for objectives and methodology of this study. None of the patients were under antimalarial therapy. Eligibility criteria were no intestinal parasite infection, parental consent for the child's participation. Patients did not receive antimalarial treatment before enrolment.

In addition, thirty-five healthy subjects uninfected by Plasmodium with similar age range and sex were chosen as the control group in the same rural area. These latter were afebrile and aparasitemic.

Parasitology: Giemsa-stained thick blood films were analysed by microscope for Plasmodium specie and parasite densities were calculated by assuming standard mean leukocyte count of $8,000 / \mu l$ (Shute, 1988). We have categorized parasite densities into three classes similarly to Ahiboh et al (2008): class A for patients presenting parasitaemia $\leq 2,000$ parasites $/ \mathrm{mm}^{3}$; class $B$ for parasitaemia between 2,000 and $40,000 / \mathrm{mm}^{3}$ and class C for parasitaemia $\geq 40,000$ parasites $/ \mathrm{mm}^{3}$.

Biological parameters: Levels of haemoglobin $(\mathrm{Hb})$ were determined using haematology cell counter( Beckmann $\mathrm{Ac}^{*} \mathrm{~T} 8$ ). Immunity (IgG, $\left.\lg \mathrm{A}, \operatorname{IgM}\right)$ and inflammatory (CRP, Haptoglobin, AGP) serum proteins were quantified by a radial immunodiffusion (RID). RID was carried out according to Mancini et al (1965) and the immunserums standards used were marketed by Dade Berhing ${ }^{\circledR}$ (Marburg RFA.).Gel of diffusion is agarose type $L$ (strength of gel $1 \%$ : $850 \mathrm{~g} / \mathrm{cm}^{2}$; electroendosmose: $\left.0,10-0,15\right)$ coming from Prolabo ${ }^{\circledR}$ (Fontenay-sous-bois, France).

Statistical analysis: Analysis was carried out on a computer using statistical software, which is SPSS 10.0. ANOVA test and $X^{2}$ test were respectively used for means and frequencies comparisons. For all test p-value $<0.05$ below was considered significant.

Ethical considerations: Informed consent and ethical approval was obtained from participants and ethical committee respectively.

Results: There were no statistically significant differences in age and sex between malaria group and control subjects. In malaria group parasite density was significantly associated with age $(p<0.01)$. The youngest $(0-5 y r)$ has higher parasite densities in contrast with other children (Table II). The Prevalence of parasitaemia is $14,9 \%$ for class A, $48,9 \%$ for class $B$ and $39,2 \%$ for class $C$. The haemoglobin was significantly decrease in malaria patients compared with the controls $(p<0.01)$.

Table III gives serum protein concentration between malaria children and controls and their distribution in different parasitaemia classes.

Serum AGP and C-reactive protein concentrations in patients were significantly higher than controls group $(p<0.01)$ but in Haptoglobin level no significant difference between patients and controls $(p>0.05)$.

Concerning humoral immune response, results show a significant increase $(p<0.01)$ in immunoglobin $M$ (IgM) concentration of patients compared to the controls whereas IgG and IgA levels remained unchanged $(p>0.05)$ in the two groups.

Comparatively to control, it has been observed a significant difference of CRP and $\alpha A G P$ in 
parasiteamia class $\geq 2,000$ parasite/ $\mathrm{mm}^{3}$ (class $B$ and C) $(p<0.05)$.

Haptoglobin level in the different parasiteamia classes ( $A, B$ ad $C$ ) was no significant difference in comparison to control group ( $p>0.05$ ).

Among immune proteins, only immunoglobin M (IgM) of malaria patients were significantly increased for parasiteamia $\geq 2000$ parasite $/ \mathrm{mm}^{3}(p<0.01)$.

Table 1. Descriptive statistics

\begin{tabular}{|l|l|l|}
\hline & $\begin{array}{l}\text { Controls } \\
(\mathbf{n}=35)\end{array}$ & $\begin{array}{l}\text { Malaria } \\
\text { patients }(\mathbf{n}=\mathbf{4 7})\end{array}$ \\
\hline Age (years) & $9.5 \pm 0,39$ & $9.7 \pm 0.27$ \\
\hline Gender (M/F) & $1.14(19 / 16)$ & $1.2(25 / 22)$ \\
\hline $\mathrm{Hb}(\mathrm{g} / \mathrm{dl})$ & $11.43 \pm 0.74$ & $9.31 \pm 0.38$ \\
\hline
\end{tabular}

$\mathrm{Hb}$ : concentration of haemoglobin
Table 2. Parasite density and age group

\begin{tabular}{|c|c|c|}
\hline Range of Age & $\begin{array}{l}\text { Parasite } \\
\left(/ \mathrm{mm}^{3}\right)\end{array}$ & signification \\
\hline$[0 ; 5]$ & 52490 & $P_{1}=0.034$ \\
\hline$] 5 ; 10]$ & 51605 & $p_{2}=0.00$ \\
\hline ]10; 15] & 33995 & $P_{3}=0.00$ \\
\hline
\end{tabular}

Table 3. Serum protein concentrations (mean $\pm S D$ ) in malaria patients and its relationship with parasitaemia levels

\begin{tabular}{|c|c|c|c|c|c|c|c|c|}
\hline \multicolumn{6}{|c|}{ Inflammatory Proteins } & \multicolumn{3}{|c|}{ Immunity proteins } \\
\hline & \multicolumn{2}{|c|}{ AGP $(g / l)$} & CRP (mg/l) & \multicolumn{2}{|c|}{$\mathrm{Hp}(g / l)$} & $\lg M(g / l)$ & $\lg G(g / l)$ & $\lg A(g / l)$ \\
\hline \multirow{2}{*}{$\begin{array}{l}\text { Study } \\
\text { subjects }\end{array}$} & $\begin{array}{l}\text { Controls } \\
(n=35)\end{array}$ & $1.37 \pm 0.43$ & \multicolumn{2}{|l|}{$8.57 \pm 5.53$} & $0.83 \pm 0,38$ & $0.54 \pm 0.41$ & $38.68 \pm 9.38$ & $6.81 \pm 4.99$ \\
\hline & $\begin{array}{l}\text { Patients } \\
(n=47)\end{array}$ & $1.71 \pm 0.45$ & \multicolumn{2}{|l|}{$13.64 \pm 6.01$} & $0.68 \pm 0.38$ & $1.73 \pm 1.35^{*}$ & $35.53 \pm 11.71$ & $4.77 \pm 5.7$ \\
\hline \multirow{3}{*}{$\begin{array}{l}\text { Parasite } \\
\text { density }\end{array}$} & Class A & $1.38 \pm 0.59$ & \multicolumn{2}{|l|}{$9.51 \pm 4.51$} & $0.65 \pm 0.77$ & $0.61 \pm 0.33$ & $39.31 \pm 11.47$ & $5.71 \pm 4.88$ \\
\hline & Class B & $1.69 \pm 0.35$ & \multicolumn{2}{|l|}{$14.00 \pm 6.16$} & $0.66 \pm 0.31$ & $1.68 \pm 1.30$ & $35.34 \pm 12.23$ & $4.79 \pm 3.87$ \\
\hline & Class C & $1.86 \pm 0.45$ & \multicolumn{2}{|l|}{$14.85 \pm 5.89$} & $0.71 \pm 0.24$ & $2.25 \pm 1.43^{\mathrm{m}}$ & $34.23 \pm 11.4$ & $4.34 \pm 8.09$ \\
\hline
\end{tabular}

Class A for parasitaemia $\leq 2,000$ parasites $/ \mathrm{mm}^{3}$, Class B for parasitaemia between 2,000 and $40,000 / \mathrm{mm}^{3}$ Class C for parasitaemia $\geq 40,000$ parasites $/ \mathrm{mm}^{3}$

Patients versus controls: * $p<0.01$

Serum proteins with parasitaemia class compared with controls: ${ }^{* *} p<0.01$

\section{DISCUSSION}

Density parasite and age: Although malaria attacks all ages, in this study high prevalence have been noticed in under 11 year old . The significant lower of parasitaemia with age could be justified by the works of Smith et al (1999) that showed that parasite density is a characteristic dependence of age. In fact we observed that high parasitaemia have been found into range 0 to five year because these children are weakly immunized contrary to those with upper ages who presents a premunition. Haemoglobin level has been reduced in malaria because its represents a main source of amino acid for parasite protein synthesis. This digestion has been operated by two protease described by Rosenthal et al (1992).

Serum proteins and malaria: At the biochemical level, according to Mansor et al (1991) and Hurt et al (1994), the significant increase of CRP and AGP concentrations indicative of inflammatory reaction during malaria, Thus, the CRP is secreted in order to 
fight against Plasmodium falciparum invasion (Volankis, 2001) . It binds damaged host cells including erythrocyte infected by Plasmodium falciparum, resulting in their clearance by both humoral and cellular immune mechanism (Ansar et al., 2006).

The biological properties of AGP are diverse. There is evidence that AGP may inhibit the multiplication of malaria parasites in vitro (Friedmann, 1983; Friedmann et al., 1984). Contrary to other studies, haptoglobin level did not change statistically because of the opposing effects of raised levels as part of inflammatory response(Gabay and Kushner, 1999) and decrease levels as a result of haemolysis (Lim et al, 2001). This latter is revealed in our study by a significant association between haptoglobin and haemoglobin in malaria children. Haptoglobin binds haemoglobin released during malaria and contribute to it decrease in plasma (Lim et al, 2001).

Moreover, Pannen et al (1995) suggested that measurement of acute phase proteins can be of diagnostic or prognostic value under certain clinical conditions. But here it seems difficult to propose useful prognostic or diagnostic markers considering their sensitivity without malaria in study area, while Hurt et al have proposed CRP as a tool in malaria epidemiology studies to measure fevers (Hurt et al, 1994).

In term of immunity, telling about immune response means that there is an increase of one or several types of immunoglobins. The significant increase of IgM in malaria could be explained by the fact that immune reaction used is of primary type, since the $\operatorname{lgM}$ are specific to it. Our results corroborate that of Jacquemin (1987). According to this author the antibodies against the different forms of parasites during malaria infection are first the $\operatorname{lgM}$, and after the IgG which could destroy parasite or favour their elimination through opsonisation and prevent merozoites from invading red cells In our study, IgG and IgA levels were no significant different between patients and controls. Because both individuals were in a similar environmental conditions influenced by antigenic stimulations (parasitose, bacterial infections...)

Serum proteins and parasite density: To study the influence of parasite densities on serum protein patterns, we have defined parasitaemia in low (class A), moderate (class B), and high (class $\mathrm{C}$ ) according to Ahiboh et al (2008). All serum protein changes has been noticed in low parasite densities. This indicates some degree of tolerance to malaria parasites in endemic area (Craig et al., 2006). In our study we have found that in malaria children CRP and AGP concentrations depended on parasitaemia levels. According to Naik and Voller (1994), the more parasite density is increase, the more both biochemical parameters are elevated too.

We also know that the serum proteins change mainly those of acute-phase proteins are not only the fact of malaria parasitaemia as revealed in previous studies (Hurt et al., (1994); Imrie et al., 2007) ,but in present study malaria appeared to be predominant in excess of 2000 parasite/ $\mu$ lin these variations.

Conclusion : Patterns of inflammatory (CRP, AGP) and immunity (IgM) blood proteins have been disrupted during malaria infection in children. These biological parameters disturbances attributable to malaria were associated with parasitaemia in excess of 2000 parasites $/ \mu$ l.

\section{REFERENCES}

Ahiboh, H., Oga, A. S., Yapi, H. F, Kouakou ,G, Boua ,K.D,. Edjeme ,N; Monnet, D.2008. Anémie, métabolisme du fer et protéines de la réaction inflammatoire au cours du paludisme (Abidjan, Cote d'ivoire). Bull. Soc .Path. Ex. 101: 25-28.

Ansar ,W, Bandyopadhyay ,S.M, Chowdhury ,S, Habib ,S.H, Mandal, C. 2006. Role of C-reactive protein in complement-mediated hemolysis in malaria. Glycoconj .J . 23: 233-240.

Beugre, G. E., Penali ,L. K., Offianan ,A. T. 2003. Aspects épidémio-cliniques et thérapeutiques du paludisme grave de l'enfant reçu dans les structures de référence en Cote d'Ivoire (Afrique de l'ouest). Med. Trop. 8: 812

Bouharoun-Tayoun, $\mathrm{H}$, Attanath, $\mathrm{P}$, Sabchareon, A, Chongsuphajaisiddhi, T, Druilhe, P .1990. Antibodies that protect humans against Plasmodium falciparum blood stages do not on their own inhibit parasite growth and invasion in vitro, but act in cooperation with monocytes. J. Exp. Med . 172:1633-1641.

Charmot, G, Vargues, R. 1963. The etiologic of macroglobulinemias observed in Africa. Sem. Hop .1421-1425.

Craig, S.B., Tsin ,W.Y, Nicholas ,M.N.2006. Malaria tolerance-for whom the cell tolls? Trends in Parasitology . 22:372-7.

Friedmann, M.J, Blankenberg, T, Sensabaugh,G, Tenforde,T.S.1984. Recognition and invasion of human erythrocytes by malaria parasites: contribution of sialoglycoproteins to attachement and host specificity. J. Cell. Biol . 98:1672-7. 
Friedmann ,M..J.1983. Control of malaria virulence by $\alpha_{1-}$ acid glycoprotein (orosomucoïd) and acute phase (inflammatory) Proc. Nat. acid. Sci .USA .80: 4521542.

Gabay ,C., Kushner ,I.1999. Acute phase proteins and other systemic responses to inflammation. N. Engl. J .Med . 40:448-454.

Garcia, L.S, Burkner, D.A.1993. Diagnostic medical parasitology. Washington : Am. Soc. Microbiol. p11331.

Hurt ,N., Smith, T., Tanner ,M., Mwankusye, S., Bordmann ,G., Weiss ,N.A. 1994. Evolution of C reactive protein and haptoglobin as malaria episode markers in area of high transmission in Africa. Trans. Roy. Soc. Trop .Med . 88: 182-186.

Imrie, H, Fowkes ,F.J, MICHON ,P, TAVUL ,L, REEDER ,J.C, DAY, K.P.2007. Low prevalence of an acute phase response in asymptomatic children from a malaria-endemic area of Papua New Guinea. Am. J .Trop .Med. Hyg. 76:280-4.

Kone ,M., Penali, L. K.1990. Situation du paludisme en Cote d'ivoire en 1990. Med Digest. 17:23-26.

Jacquemin ,J. C.1987. Le paludisme. Par Clin, $3^{\mathrm{e}}$ ed. Paris. ill 21(abrégé de médecine) : 18-35.

Latger-Cannard, V., Bibles, B., Dao, A., Fohlen-Walter, A., Buisine ,J., Rabaud, C.2002. Infection à Plasmodium et cytopénie. Ann. Biol .Clin . 60: 213-216.

Lim, S.K, Ferraro, B, Moore, K, Halliwell, B. 2001. Role of haptoglobin in free haemoglobin metabolism. Redox .Rep. 6:219-27.
Mancini, G., Carbonara, A. O, Hermans ,J. F..1965. Immunochimical quantification of antigens by single radial immunodiffusion. Immunochemistry . 2 : 235-54.

Mansor ,S.M, Molyneux ,M.E, Taylor ,T.E, Ward, S.A, Wirima, J.J, Edwards, G.1991.Effect of Plasmodium falciparum on the plasma concentration of Alpha-acid glycoprotein and binding of quinine in Malawian children. Br. J. Clin. Pharmac . 32:317-321.

NAIK ,P., Voller ,A.1994.Serum C reactive protein levels and falciparum malaria. Trans. Roy. Trop. Med. 78: 812813.

Pannen, B.H.J., Robotham, J.L.1995. The acute-phase response. New. Horiz. 3:183-197.

Plebanski, M, Hill, A.V.S.2000.The immunology of malaria. Curr. Opin. Immunol . 12:437-441.

Rosenthal, P., Nelson ,R. G.1992.Isolation and characterization of a cysteine proteinase gene of Plasmodium falciparum. Mol .Biochem. Parasitol. 51:143-152.

Shute ,G. T.1988. The microscopic diagnosis of malaria, W $\mathrm{H}$ Wernsdorfer and I. McGregor, In Malaria p805 (ed) vol.1 Churchill Livingstone, Ltd Edibburgh.

Smith, T., Beck ,H. P.,Kitua ,A., SMWAMKUSY,E, FELGER, I.1999.Age dependence of multiplicity of Plasmodium malariae infections and others malariological indice in area of high endemicity. Trans .Roy. Soc. Trop. med .Hyg. 93:15-20.

Volanakis ,J.E. 2001. Human C-reactive protein: expression, structure, and function. Mol .Immunol . 38:189-97.

Tripathi ,R. P., Mishra, R. C., Dwivedi ,N., Tewari ,N., Verma, S. S. 2005. Current status of malaria control. Curr. Med. Chem . 12: 2643-2649.

White, NJ. 1992. Antimalarial drug resistance: the pace quickens. J Antimicrob. Chemother. 30: 571-585. 